\title{
ANÁLISE DO TRATAMENTO TERMINOLÓGICO DOS TEXTOS DO MUSEU DE CIÊNCIAS E TECNOLOGIA DA PUCRS E SUA RELAÇÃO COM A SITUACIONALIDADE
}

\author{
Lucas Meireles Tcacenco \\ Submetido em 10 de maio de 2019. \\ Aceito para publicação em 06 de setembro de 2019. \\ Cadernos do IL, Porto Alegre, n. ${ }^{\circ}$ 59, outubro. p. 347-369.
}

\section{POLÍTICA DE DIREITO AUTORAL}

Autores que publicam nesta revista concordam com os seguintes termos:

(a) Os autores mantêm os direitos autorais e concedem à revista o direito de primeira publicação, com o trabalho simultaneamente licenciado sob a Creative Commons Attribution License, permitindo o compartilhamento do trabalho com reconhecimento da autoria do trabalho e publicação inicial nesta revista.

(b) Os autores têm autorização para assumir contratos adicionais separadamente, para distribuição não exclusiva da versão do trabalho publicada nesta revista (ex.: publicar em repositório institucional ou como capítulo de livro), com reconhecimento de autoria e publicação inicial nesta revista.

(c) Os autores têm permissão e são estimulados a publicar e distribuir seu trabalho online (ex.: em repositórios institucionais ou na sua página pessoal) a qualquer ponto antes ou durante o processo editorial, já que isso pode gerar alterações produtivas, bem como aumentar o impacto e a citação do trabalho publicado.

(d) Os autores estão conscientes de que a revista não se responsabiliza pela solicitação ou pelo pagamento de direitos autorais referentes às imagens incorporadas ao artigo. A obtenção de autorização para a publicação de imagens, de autoria do próprio autor do artigo ou de terceiros, é de responsabilidade do autor. Por esta razão, para todos os artigos que contenham imagens, o autor deve ter uma autorização do uso da imagem, sem qualquer ônus financeiro para os Cadernos do IL.

\section{POLÍTICA DE ACESSO LIVRE}

Esta revista oferece acesso livre imediato ao seu conteúdo, seguindo o princípio de que disponibilizar gratuitamente o conhecimento científico ao público proporciona sua democratização.

http://seer.ufrgs.br/cadernosdoil/index

Terça-feira, 29 de outubro de 2019. 


\title{
ANÁLISE DO TRATAMENTO TERMINOLÓGICO DOS TEXTOS DO MUSEU DE CIÊNCIAS E TECNOLOGIA DA PUCRS E SUA RELAÇÃO COM A SITUACIONALIDADE
}

\author{
ANALYSIS OF THE TREATMENT OF TERMINOLOGIES \\ IN TEXTS OF PUCRS' SCIENCE AND TECHNOLOGY \\ MUSEUM AND THEIR RELATIONSHIP WITH \\ SITUATIONALITY
}

Lucas Meireles Tcacenco*

\begin{abstract}
RESUMO: Museus de ciências e tecnologia estimulam o gosto pela ciência no jovem. Logo, faz-se mister conduzir uma análise dos textos lá apresentados para avaliar o seu funcionamento. Em nossa análise, adotamos dois pontos de vista: o da terminologia e o do funcionamento textual no que diz respeito ao fator de textualidade denominado situacionalidade. Para tanto, utilizaremos um corpus de textos constantes nos experimentos do MCT-PUCRS. Como fundamentação teórica, valemo-nos das contribuições das perspectivas textuais da Terminologia e da Linguística Textual e das ideias de Guiomar Ciapuscio. Os resultados indicam que o tipo de tratamento terminológico pode conectar-se com a promoção da situacionalidade. Ao fim, avaliamos os resultados obtidos e sugerimos pesquisas com outros gêneros textuais e com outros critérios de textualidade.
\end{abstract}

PALAVRAS-CHAVE: Museu de ciências e tecnologia; Situacionalidade; Perspectivas Textuais da Terminologia.

ABSTRACT: Science and technology museums aim to develop the taste for science in the youth. Therefore, it is important to investigate how museum texts function. Two points of view were adopted: the perspective of Terminology and of the textuality factor known as situationality as it concerns the organization and structure of the text. Hence, a corpus of texts lifted from MCT-PUCRS was studied. Our analyses drew insights from the textual perspectives of Terminology, Text Linguistics, and the ideas of Guiomar Ciapuscio. Results show that the type of terminology treatment can have a role to play in the promotion of situationality. Lastly, we look at the results and make suggestions for research involving other text genres and other standards of textuality.

KEYWORDS: Science and technology museum; Situationality; Textual perspectives of Terminology.

\section{Introdução}

Museus de ciências e tecnologia têm por objetivo estimular o apreço dos seus visitantes pelos fenômenos e conhecimentos relacionados aos domínios dos quais eles se ocupam. As exibições disponibilizadas nesse tipo de museu consistem, em sua maioria, em experimentos - interativos ou não - acompanhados de legendas - textos descritivos, explicativos ou de orientação. Como a apropriação do conhecimento é fortemente dependente do uso exitoso dos experimentos e esse sucesso se dá, em grande

\footnotetext{
* Doutorando em Estudos da Linguagem pela Universidade Federal do Rio Grande do Sul, lucasmtcacenco@msn.com.
} 
medida, através da linguagem apresentada, faz-se mister conduzir uma análise, sob o viés dos estudos da linguagem, que avalie se os textos vão ao encontro dos propósitos inerentes a esse tipo de museu. Consideramos como sendo um requisito fundamental a apresentação dos textos em uma linguagem acessível para que o visitante possa ter uma experiência museológica satisfatória e se entusiasme pelo mundo das ciências e da tecnologia. Aqui se define linguagem acessível como uma linguagem que trabalha os traços e termos marcadamente especializados no âmbito do léxico, sintaxe, pragmática e gramática e que apresenta características mais próximas às da linguagem geral. A linguagem acessível também pode apresentar número controlado de palavras por frase, frases e parágrafos menores - mas nem sempre -, além de fazer uso de elementos semióticos para facilitar o entendimento por parte de quem lê. Essa linguagem facilitada, que tende a se pautar por uma análise do público consumidor do texto, irá garantir acesso a informações e conceitos complexos da vida humana por parte do cidadão com baixo letramento.

Neste estudo, os textos constantes nos totens do Museu de Ciências e Tecnologia da PUCRS (MCT-PUCRS) serão nosso objeto de escrutínio, à luz das perspectivas textuais da Terminologia. O MCT-PUCRS é uma referência no sul do Brasil, tendo ganhado vários prêmios nacionais. Seu rol de ações em prol da formação do cidadão inclui exposições e atividades de divulgação científica, formação de professores, trabalhos com escolas, entre outras. Algumas de suas exposições são intercambiadas com museus de outros países, como o da Newcastle University, no Reino Unido.

As perspectivas textuais da Terminologia (TT) conforme são trabalhadas por Ciapuscio (1998) e Hoffmann (2015a, 2015b) são tributárias à Linguística Textual (LT), e têm o texto como seu objeto particular de estudo. Uma máxima que é preconizada por Beaugrande e Dressler (1981), autores referenciais da LT, é que para um texto apresentar textualidade, isto é, funcionar como unidade comunicativa, ele deve preencher alguns requisitos. São eles: a) coesão, b) coerência, c) intencionalidade, d) aceitabilidade, e) informatividade, f) situacionalidade e g) intertextualidade. Esses requisitos são chamados de fatores de textualidade por diferentes autores da LT, tais como Halliday e Hasan (1976) e Koch (2004).

Nosso estudo se debruça sobre a situacionalidade, uma designação geral que diz respeito a um dos "fatores que tornam um texto relevante a uma situação comunicativa em curso ou passível de ser reconstituída" (BEAUGRANDE; DRESSLER, 1981, p. 162, tradução nossa) ${ }^{1}$. Mais adiante, esse fator será mais bem apresentado. Nos limites deste estudo, "texto" é entendido como um todo complexo e multifacetado, que compreende a dimensão da significação e da comunicação. No âmbito da significação, situa-se a dimensão de estrutura ou tessitura. Por outro lado, no âmbito da comunicação, temos uma série de elementos discursivos, tais como propósitos da interação via texto e efeitos de sentido, como narração, descrição ou o propósito do texto (FIORIN, 1995; BARROS, 2011).

\section{Fundamentação teórica}

Passamos agora a apresentar os principais conceitos envolvidos neste trabalho, especialmente o tratamento terminológico e o fator de textualidade em questão. Por uma

\footnotetext{
${ }^{1}$ Este trecho foi adaptado por nós a partir do original em inglês: "factors which render a text relevant to a current or recoverable situation of occurrence".
} 
questão cronológica, será primeiro apresentada a LT e o seu tratamento sobre fatores de textualidade. Em seguida, discorremos sobre a Terminologia, as perspectivas textuais de Terminologia, visto que elas reelaboram os princípios da LT, assim como as Linguagens Especializadas.

\subsection{Linguística Textual}

A Linguística Textual é um viés da Linguística que se vale do texto como unidade de estudo, em contraponto às perspectivas anteriores, que se valiam da frase e de outras unidades menores (MARCUSCHI, 2008). Essa mudança de paradigmas se deu pelo fato de unidades menores, como a frase e a palavra, não darem conta de explicar vários fenômenos linguísticos. A Linguística Textual teve suas origens na Alemanha, e seus maiores expoentes foram Beaugrande e Dressler (1981) e Halliday e Hasan (1976).

No Brasil, os trabalhos de Marcuschi (2008), Fávero e Koch (1988) e Koch e Travaglia (1990) são os de maior relevância nessa área. Marcuschi (2008, p. 88) defende que "o texto é a unidade máxima de funcionamento da língua". O autor argumenta que, independentemente do tamanho, o texto será uma unidade de "caráter funcional" e que "o que faz um texto ser um texto é a discursividade, inteligibilidade e articulação que ele põe em andamento" (MARCUSCHI, 2008, p. 89). Isso é o que difere um texto de um amontoado de frases ou palavras isoladas. Quando esses fatores se integram, pode-se dizer que há textualidade. O mesmo autor postula que "um texto se dá numa complexa relação interativa entre a linguagem, a cultura e os sujeitos históricos que operam nesses contextos" (MARCUSCHI, 2008, p. 99).

Para que haja textualidade, Beaugrande e Dressler (1981) avaliam que há de haver uma confluência de fatores. Dentre tais fatores, o que nós nos atemos neste trabalho é a situacionalidade. Koch e Travaglia (1990) argumentam que a situacionalidade pode ser considerada em duas direções: da situação para o texto e do texto para a situação. Na primeira direção, trata-se de

\footnotetext{
determinar em que medida a situação comunicativa interfere na produção/recepção do texto e, portanto, no estabelecimento da coerência. A situação deve ser aqui entendida quer em sentido estrito - [...] o contexto imediato da interação - quer em sentido amplo, ou seja, o contexto sóciopolítico-cultural em que a interação está inserida (KOCH; TRAVAGLIA, 1990, p. 69-70).
}

Os autores elencam o grau de formalidade, a variedade dialetal e o tratamento a ser dado ao tema como fatores que podem ter alguma interferência na situação comunicativa. Já na outra direção, os autores discorrem sobre a necessidade de se ter em mente que o texto tem importantes reflexos sobre a situação, visto que "o mundo textual não é jamais idêntico ao mundo real" (KOCH; TRAVAGLIA, 1990, p. 70). A mediação entre produtor de textos e interlocutor é uma constante. O produtor "reconstrói o mundo de acordo com suas experiências, seus objetivos, propósitos, convicções, crenças, etc." (KOCH; TRAVAGLIA, 1990, p. 70). Quanto ao receptor, a sua interpretação se dá conforme "sua ótica, os seus propósitos, as suas convicções" (KOCH; TRAVAGLIA, 1990, p. 70).

Marcuschi (2008) diz que 
a situacionalidade é uma forma particular de o texto se adequar tanto a seus contextos como a seus usuários. Se um texto não cumprir os requisitos de situacionalidade, não poderá se "ancorar" em contextos de interpretação possíveis, o que o torna pouco proveitoso (MARCUSCHI, 2008, p. 129).

Considerando um museu de ciência e tecnologia, que é frequentado por indivíduos de várias faixas etárias que podem não ter nenhum conhecimento acerca dos tópicos abordados nas exposições, há de se verificar se os textos apresentados estão adequados ao contexto e aos usuários. Nesse sentido, serão observados o grau de formalidade, a variedade dialetal empregada e o tratamento a ser dado ao tema, com foco em termos e conceitos.

\subsection{Linguagens especializadas, Terminologia e perspectivas textuais}

Terminologia, grafada com T maiúsculo, no Brasil corresponde a uma área dos estudos de Linguística Aplicada que se dedica à descrição dos fenômenos das linguagens especializadas.

As linguagens especializadas são, nesse âmbito, entendidas como práticas de comunicação que envolvem a veiculação de informação técnico-científica num contexto profissional ou de formação qualquer. Pode-se dizer, então, que a veiculação dessas informações é materializada nos textos especializados. Zílio (2015), em sua tese de doutorado, argumenta que dentre as características textuais mais comumente encontradas em textos especializados pode-se citar a alta incidência de voz passiva, a alta incidência de sintagmas preposicionados e a omissão dos agentes das orações, sendo esses substituídos por instrumentos ou pela própria voz passiva.

Ao longo de seu desenvolvimento, a Terminologia parte de uma perspectiva prescritiva para um encaminhamento majoritariamente descritivo. Esse encaminhamento se inicia com a unidade lexical terminológica - o termo e o conceito a que ele corresponde - passando pelos fraseamentos das linguagens especializadas, abrangendo as definições e, por fim, o texto especializado como um todo de significação e de comunicação. Nesse percurso, instauram-se as perspectivas textuais da Terminologia.

Um dos maiores expoentes das perspectivas textuais da Terminologia é o professor alemão Lothar Hoffmann. Para ele, a linguagem especializada é "o conjunto de todos os recursos linguísticos que são utilizados em um âmbito comunicativo, delimitado por uma especialidade, para garantir a compreensão entre as pessoas que nele atuam" (HOFFMANN, 2015a, p. 40-41). Esses recursos linguísticos incluem, entre outras coisas, o vocabulário especializado, as terminologias (termos), além de determinadas categorias gramaticais, determinadas estruturas sintáticas e textuais.

É, então, correto afirmar que uma linguagem especializada possui, entre outras coisas, um vocabulário especializado. Hoffmann (2015a, p. 43) define vocabulário especializado como "todas as unidades lexicais contidas em textos especializados, já que essas unidades contribuem para a comunicação especializada de uma maneira direta ou indireta". O autor também argumenta que, por outro lado, "o vocabulário especializado, num sentido mais estrito, forma um subsistema do sistema léxico global, quer dizer, um subconjunto do vocabulário total de uma língua" (HOFFMANN, 2015a, p. 43). Ele salienta que nesse tipo de vocabulário "predominam substantivos e adjetivos 
em relação aos verbos e às outras classes de palavras, pois é preciso designar a multiplicidade de objetos e manifestações que caracterizam a atividade especializada" (HOFFMANN, 2015a, p. 43). Em que pese o papel central do componente lexical, o macroplano do texto é entendido como um signo linguístico fundamental, o que é um pensamento diretamente derivado da LT antes citada.

No tocante às terminologias, pode-se afirmar que todo o texto inclui termos. Krieger e Finatto (2004) argumentam que, atualmente, a Terminologia exerce um papel social fundamental na comunicação e que cada vez mais o interesse por temas de interesse científico e tecnológico tornaram-se objetos de interesse de públicos não especializados. Consequentemente, o conteúdo dessas linguagens especializadas afeta o cotidiano das pessoas, de maneira geral, já que as terminologias passam a fazer parte de seu repertório.

\footnotetext{
A existência e a circulação de terminologias em distintos cenários comunicativos são testemunhos de que essas cumprem, prioritariamente, a dupla função de fixar o conhecimento técnico científico e de promover sua transferência de modo plural (KRIEGER; FINATTO, 2004, p. 19).
}

A constatação acima pode ser dignamente exemplificada em diferentes contextos, por exemplo, nos livros didáticos de Ciências (Química, Física, Biologia e Matemática), que têm a função de introduzir o aluno ao mundo científico e, também, nos museus de ciência e tecnologia, cuja finalidade é promover o entusiasmo desses indivíduos - e também dos adultos - por ciência e tecnologia.

Krieger e Finatto (2004, p. 106) advogam que, devido ao texto ser o "habitat natural das terminologias", uma abordagem textual que o conceda como objeto de comunicação entre destinador e destinatário privilegia "o exame do comportamento das unidades terminológicas em seu real contexto de ocorrência, compreendendo que essas unidades aparecem de maneira natural no discurso" (KRIEGER; FINATTO, 2004, p. 106-107). Essa mesma abordagem textual, conforme as autoras, "tem permitido identificar, por exemplo, os fatores pragmáticos da comunicação especializada que ativam a feição terminológica que distintas unidades lexicais assumem no contexto das comunicações especializadas" (KRIEGER; FINATTO, 2004, p. 107).

Hoffmann vê o texto como signo linguístico primário, isto é, sob condições normais, a linguagem se realiza apenas por meio de textos. E isso vale também para o texto especializado. Ele define o texto especializado como um "instrumento e, ao mesmo tempo, resultado da atividade comunicativa exercida em relação a uma atividade especializada sócio produtiva" (HOFFMANN, 2015a, p. 47).

Nesse enfoque linguístico-textual da Terminologia, a questão dos cenários comunicativos exerce bastante influência tanto sobre quem está produzindo o texto quanto para quem o está consumindo. Essa perspectiva, acompanhada por Pearson (1998), estabelece um parâmetro situacional-comunicativo para caracterizar e descrever a presença de terminologias em vista das partes envolvidas na atividade comunicativa. As situações são as seguintes: especialista/especialista; especialista/iniciados; especialista mediano/leigo e professor/aluno. Considerando o contexto comunicativo de um museu de ciência e tecnologia cujo público alvo consiste, em sua maioria, em jovens em idade escolar, consideraremos, nos estudos dos textos que nos interessam, a terceira categoria de interlocução estabelecida por Pearson: a do especialista mediano autor do texto para o leigo que visita o museu. 
Visto por esse ângulo, os textos constantes nas legendas dos experimentos do MCT-PUCRS poderiam ser considerados como textos especializados, onde há a necessidade de adequação linguística e terminológica em vista do seu público consumidor. Essa preocupação com a gradação do nível de especialidade do texto especializado já havia sido levantada por Hoffmann (2015b). Dentre os trabalhos que se inclinaram às suas postulações concernentes à acessibilização da linguagem, podemos citar os de Leipnitz (2005), Silva (2018), Motta (2018), entre outros.

\subsection{Tratamento terminológico}

O tratamento terminológico corresponde a uma série de processos relacionados ao modo de apresentação das terminologias e dos conceitos ao longo de um dado texto. Em investigações prévias sobre o tratamento terminológico em textos especializados, Ciapuscio (1998) verificou que a produção de divulgação científica de textos para leigos e semileigos apresentava uma forte tendência à reformulação denominativa dos termos.

Esse tratamento poderia ser ora parafrástico, através de definições ou explicações, ora não parafrástico, constituindo-se de sequências que apresentam informação enciclopédica para facilitar a compreensão do termo e entendimento de determinado fenômeno ou conceito. Ciapuscio (1998, p. 14) considera esse tipo de reformulação como sendo uma "terminologia estendida". A autora reivindica os fatores de ordem funcional e situacional, tais como os interlocutores, o gênero textual e o próprio âmbito discursivo como fatores condicionantes ao tratamento dado aos termos. Os diferentes tipos de tratamento terminológico abordados por Ciapuscio serão tentativamente descritos e analisados no nosso corpus de pesquisa.

\section{Metodologia e corpus de pesquisa}

Trazemos aqui a descrição e análise de um texto da exposição Marcas da Evolução no MCT-PUCRS. Os textos que acompanham exposições museológicas podem ser de várias tipologias. Em investigações prévias, Pereira e Valle (2017) evidenciaram placas de orientação, etiquetas de identificação de obras e objetos, placas informativas e quadros como tipologias constantes em um museu de Paleontologia. ${ }^{2}$ Essas mesmas tipologias estão constantes no MCT-PUCRS, tanto em formato físico quanto digital (na tela de totens ou de dispositivos digitais, como smartphones ou tablets, já que alguns experimentos e textos podem ser disponibilizados através de um leitor de QR Code). À lista de Pereira e Valle, acrescentamos os panfletos e manuais como tipos de textos passíveis de serem encontrados em museus, em geral.

A exposição Marcas da Evolução foi um dos grandes destaques do ano de 2017, tendo sido exibida, inclusive, no Great North Museum, da Newcastle University, no Reino Unido. O texto selecionado para análise intitula-se Evidências da Evolução. Ele é

\footnotetext{
${ }^{2}$ Nos museus existem diferentes tipos de textos que são oferecidos aos visitantes de uma exposição ou do museu como um todo. Basicamente, pode-se imaginar duas categorias de textos: a) aqueles textos que se encontram como peças anexas a elementos expostos ou experimentos e b) textos independentes de peças, tais como catálogos e diferentes impressos entregues aos usuários, que podem ser compreendidos independentemente de uma conexão explícita e direta com um determinado objeto de uma exposição. As placas antes mencionadas e as legendas inserem-se no primeiro grupo.
} 
dividido em quatro blocos: "Homologia morfológica", "Homologia ontogenética", "Homologia molecular" e "Paleontologia". Cada bloco apresenta algumas ideias centrais acerca do tópico a que se refere.

Ao chegar à área da exposição, no segundo andar do museu, em meio ao ambiente decorado com esqueletos de animais e humanos, os visitantes utilizam um totem para ter acesso às informações sobre os itens mencionados nos quatro blocos referidos no parágrafo anterior. Na tela inicial, aparece uma breve introdução sobre a exposição que convida os visitantes a dar continuidade à visita, ao tocar na tela. Assim, o texto sob análise tem um funcionamento e uma natureza que são peculiares. No nosso caso, o texto é um suplemento para o insumo visual do entorno (Figura 1).

\section{Fonte: MCT-PUCRS}

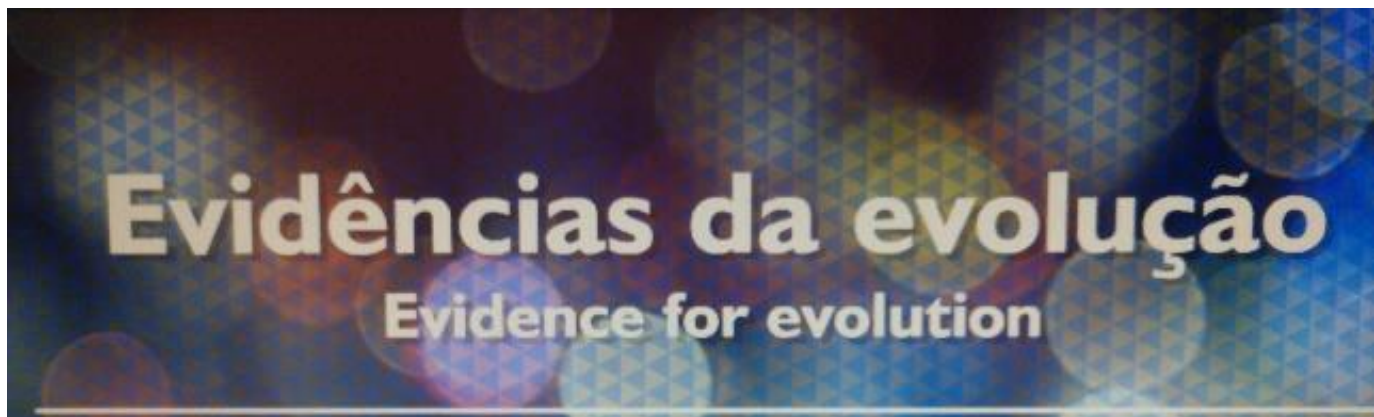

As homologias (similaridades) morfológica, ontogenétic:

evidencias que comprovam a ancestralidade comum e, porch inito, a evoluctio

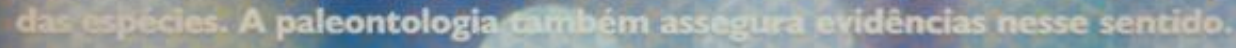

The morphalopical onto renetic and

ancestar and, conseguently.

(4)

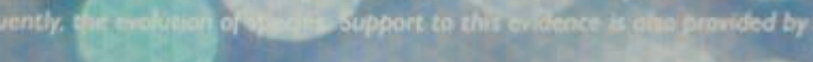

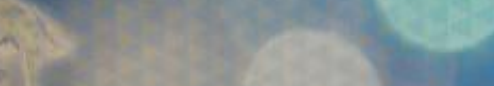

Figura 1 - Tela inicial do totem da exibição Marcas da Evolução

Após tocar na tela, os visitantes são direcionados a uma página em que aparecem quatro opções do lado esquerdo. Essas opções descrevem, com algum detalhe, os quatro subtítulos mencionados parágrafo anterior (Figura 2). 


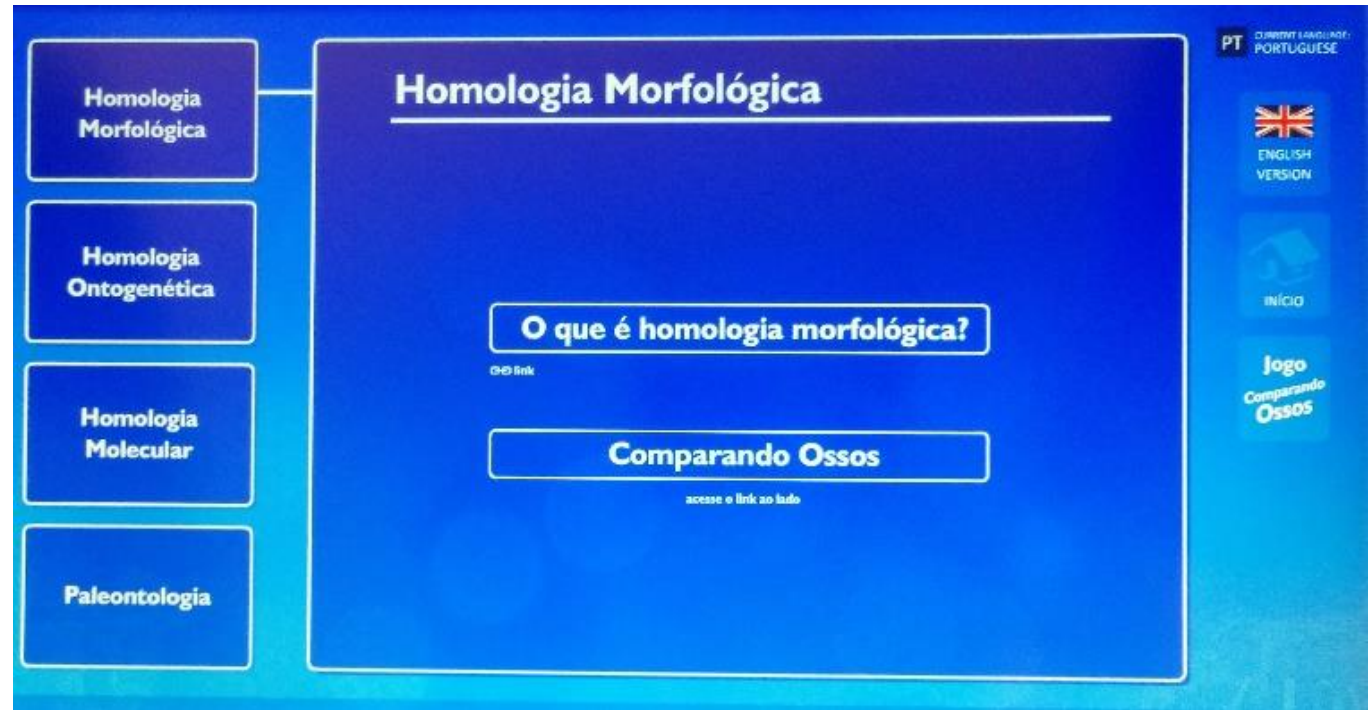

Figura 2 - Tela do totem da exibição Evidências da Evolução com as quatro opções

Nessa tela, eles têm a opção de dar seguimento às explicações, clicando em "O que é Homologia Morfológica?" ou de jogar um jogo lúdico. Clicando em "Comparando Ossos", o visitante é direcionado a uma tela que apresenta a ossada de um animal não identificado e seis opções de animais para que cliquem no animal que acreditam pertencer à ossada (Figura 3). Após o clique, a resposta aparece automaticamente.

Fonte: MCT-PUCRS

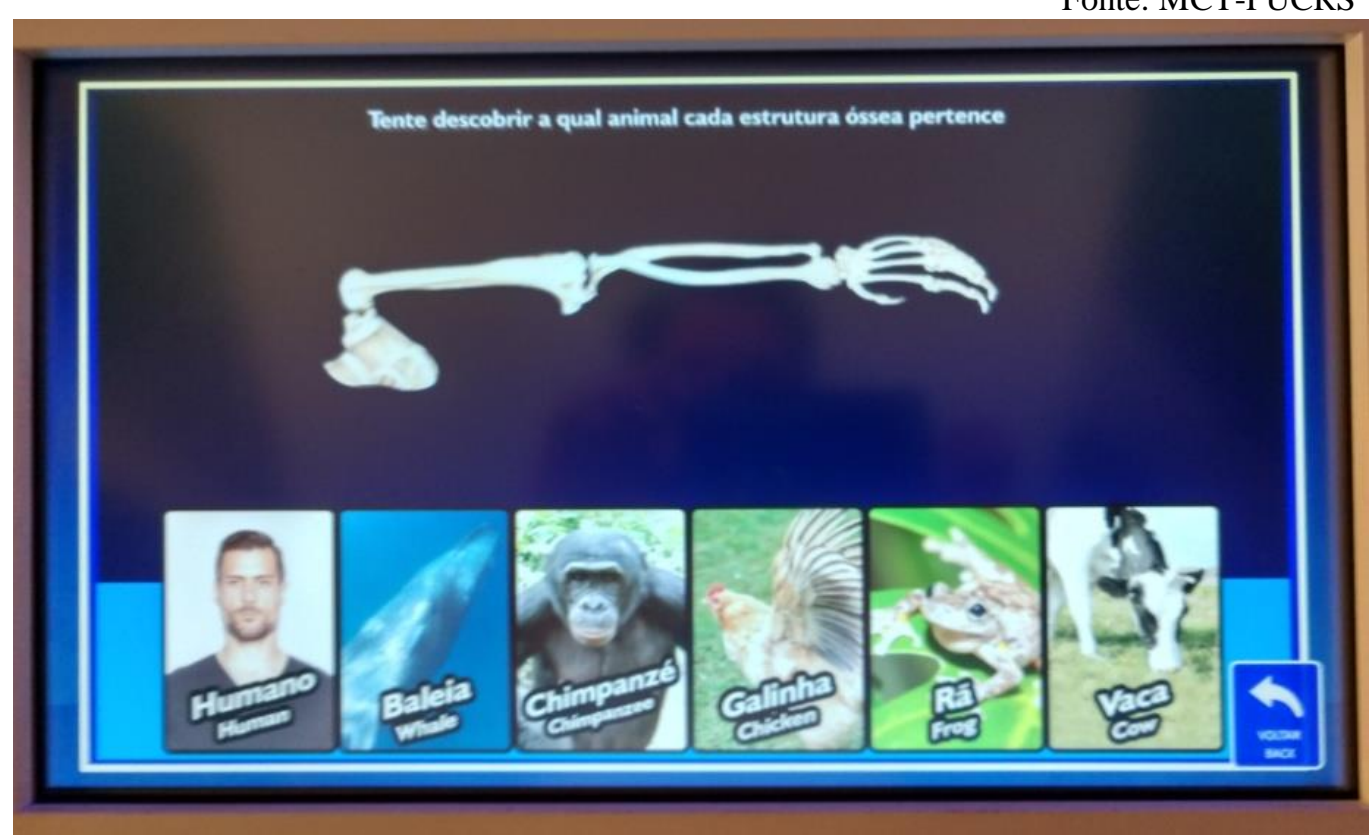

Figura 3 - Jogo lúdico sobre de identificação das ossadas 
Optamos por não incluir os nomes dos animais constantes nessa tela em nossa análise justamente por estarem isolados do grande macrotexto. Pela mesma razão, também deixamos de fora da nossa análise as legendas da imagem apresentada no subtexto sobre a homologia morfológica que se referem à estrutura esquelética da cobra, que incluem os termos "estrutura esquelética", "membros posteriores rudimentares", "superfície externa" e "terminação dos membros posteriores". Esses termos são usados para ilustrar a localização de alguns ossos específicos desse animal, "pelve" e "fêmur", que são mencionados no texto, e "ísquio", que é mencionado apenas na imagem (Figura 4).

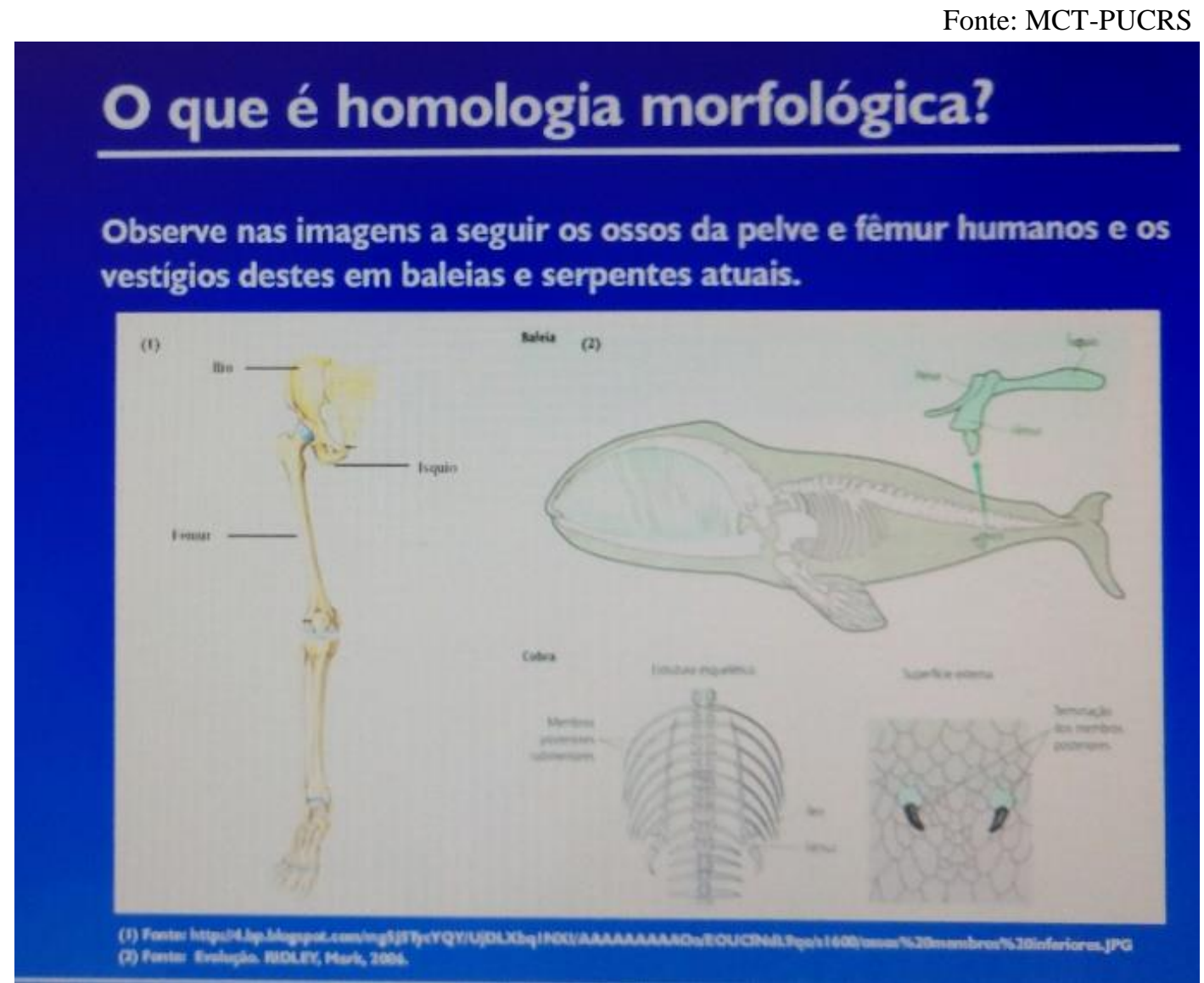

Figura 4 - O que é homologia morfológica?

\subsection{Da compilação do corpus e extração de candidatos a termos}

O nosso corpus, que corresponde apenas à parte verbal do texto, foi compilado em um documento com extensão .txt. Tem 867 palavras no total, incluindo 63 que são apresentadas como legenda de uma imagem retirada de um livro ${ }^{3}$.

Para que seja possível observar o tipo de tratamento terminológico, é necessário que antes se identifique a terminologia presente no texto. Logo, procedemos a uma extração ou identificação terminológica. Inicialmente, conduzimos uma análise manual

\footnotetext{
${ }^{3}$ Este último trecho, constante no bloco referente à Paleontologia, foi retirado de Reece et al (2013).
} 
na qual selecionamos 39 potenciais candidatos a termos. Essa análise será conjugada a uma segunda, complementar, realizada com apoio computacional.

No esforço de confirmar nossa primeira listagem manualmente obtida, fizemos uso de uma ferramenta automática de extração de candidatos - o Sketch Engine (doravante SE). Compilamos o corpus e extraímos os candidatos a termo também com o auxílio dessa ferramenta. Ela faz uma série de comparações estatísticas entre corpus de estudo e corpora de referência e indica as palavras ou grupos de palavras que têm uma apresentação peculiar.

O SE, aplicado ao corpus de estudo, produz duas listas diferentes: uma de unigramas (unidades especializadas monoléxicas nominais) e outra de multigramas (unidades especializadas poliléxicas nominais). Utilizamos o Portuguese Web 2011 como corpus de referência, um corpus que consiste de 3.896.392.719 palavras. Em nosso estudo, cotejamos a lista produzida manualmente com a lista produzida pelo programa. Reproduzimos a seguir um pequeno trecho do texto sob análise, o qual se encontra na íntegra no Apêndice A. Assim, acreditamos, que o acompanhamento da geração de listas fique um pouco mais facilitado.

Homologia morfológica refere-se às similaridades entre estruturas anatômicas - como ossos e demais órgãos - e constitui-se em evidências da ancestralidade comum entre os seres vivos que as compartilham.

Os membros anteriores de uma galinha, de um humano e de uma baleia não executam a mesma função, ou seja, enquanto a asa da galinha é usada para voar, a mão do humano é usada para manusear e a nadadeira da baleia, para nadar.

Apesar de sua adaptação a funções distintas, nota-se que a estrutura óssea básica desses membros é a mesma, o que indica uma relação de parentesco entre esses animais. (Fonte: MCTPUCRS).

Embora o software produza uma lista de termos com frequências variadas, quase todos os que nós havíamos selecionado manualmente constam na contagem do programa. Os termos "homologias" e "genes" são apresentados na lista do SE, mas na forma singular: "homologia" e "gene". Apesar das variações, ainda sustentamos as duas palavras como sendo termos no nosso contexto de estudo. O termo "ancestral direto" não figurava entre os 100 primeiros termos da lista do programa. Ainda assim, na nossa análise, o consideramos como termo.

Seguem listados no Quadro 1 os candidatos a termos selecionados manualmente no corpus dos textos do MCT-PUCRS, que inclui as unidades especializadas monoléxicas nominais e unidades especializadas poliléxicas nominais:

Quadro 1 - Candidatos a termos selecionados manualmente

\begin{tabular}{|l|l|}
\hline Número & Item \\
\hline 1 & Homologias \\
\hline 2 & Ancestralidade comum \\
\hline 3 & Paleontologia \\
\hline 4 & Homologia morfológica \\
\hline
\end{tabular}




\begin{tabular}{|l|l|}
\hline 5 & Estruturas anatômicas \\
\hline 6 & Membros anteriores \\
\hline 7 & Estrutura óssea básica \\
\hline 8 & Orgãos vestigiais \\
\hline 9 & Pelve \\
\hline 10 & Fêmur \\
\hline 11 & Tetrápodes terrestres \\
\hline 12 & Coluna vertebral \\
\hline 13 & Membros inferiores \\
\hline 14 & Espinhos abdominais \\
\hline 15 & Estruturas homólogas \\
\hline 16 & Semelhanças anatômicas \\
\hline 17 & Radiação adaptativa \\
\hline 18 & Estruturas análogas \\
\hline 19 & Convergência adaptativa \\
\hline 20 & Ancestral direto \\
\hline 21 & Homologia ontogenética \\
\hline 22 & Desenvolvimento embrionário \\
\hline 23 & Arcos faríngeos \\
\hline 24 & Brânquias \\
\hline 25 & Processo de diferenciação \\
\hline 26 & Tubo neural \\
\hline 27 & Notocorda \\
\hline 28 & Eixo de sustentação \\
\hline 29 & Desenvolvimento corporal \\
\hline 30 & Material genético \\
\hline 31 & Unidades químicas \\
\hline 32 & Bases nitrogenadas \\
\hline 33 & Genes \\
\hline 34 & Registros fósseis \\
\hline 35 & Fósseis \\
\hline 36 & Rochas sedimentares \\
\hline 37 & História evolutiva \\
\hline 38 & Homologia molecular \\
\hline 39 & Embrião \\
\hline & \\
\hline
\end{tabular}

\section{Resultados}

Após a análise dos 39 termos selecionados pelo pesquisador e confirmados pela ferramenta, constantes em nossa investigação, concluímos que, de maneira geral, diferentes tipos de tratamento são dados às terminologias. São eles:

a) Paráfrase explanatória: o produtor dos textos optou por não reformular muitos dos termos, mas apresentar uma definição dos mesmos na sequência do texto;

b) Compensação pelo uso de elementos semióticos: alguns termos foram apresentados no texto e ilustrados através de imagens. Tratando-se de um museu 
de ciência e tecnologia, as imagens desempenham um papel fundamental na produção do significado e construção do conhecimento;

c) Inclusão de sinônimos entre parênteses: o recurso da sinonímia, seja ela entre parênteses, hifens ou outros sinais, também é empregado no texto para auxiliar o visitante com baixo letramento;

d) Tratamento não reformulativo: em alguns casos, optou-se por dar exemplos reais e concretos dos conceitos aos quais os termos se referem, de forma enciclopédica, sem ter que defini-los;

e) Nenhum: em alguns casos, as terminologias constantes no texto não receberam nenhum tipo de tratamento.

No Quadro 2, seguem os resultados da nossa análise em vista dos tipos de tratamento terminológico elencados acima.

Quadro 2 - Tratamento terminológico dos termos no texto Evidências da Evolução

\begin{tabular}{|c|c|}
\hline Tipo de tratamento & Termos \\
\hline a) Paráfrase explanatória & 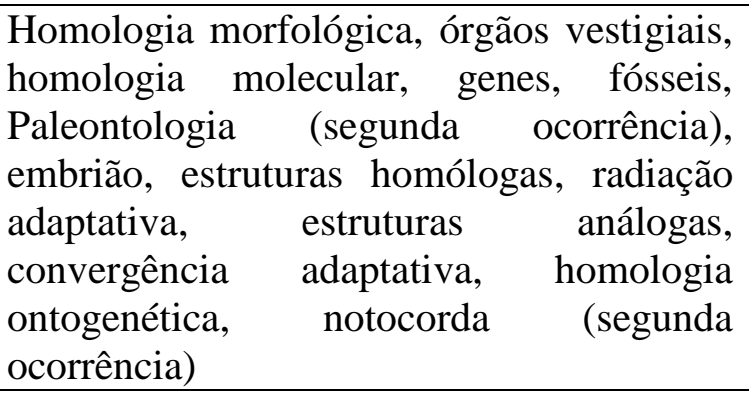 \\
\hline $\begin{array}{l}\text { b) Compensação por elementos } \\
\text { semióticos }\end{array}$ & $\begin{array}{l}\text { Fêmur, estrutura óssea básica, } \\
\text { desenvolvimento embrionário, espinhos } \\
\text { abdominais, processo de diferenciação, } \\
\text { rochas sedimentares }\end{array}$ \\
\hline $\begin{array}{l}\text { c) Inclusão de sinônimos entre } \\
\text { parênteses }\end{array}$ & $\begin{array}{l}\text { Homologias }- \text { similaridades, rochas } \\
\text { sedimentares } \\
\text { estratos }\end{array}$ \\
\hline d) Tratamento não reformulativo & $\begin{array}{l}\text { Estruturas anatômicas, } \\
\text { anteriores, estruturas análogas }\end{array}$ \\
\hline e) Nenhum & $\begin{array}{l}\text { Ancestralidade comum, Paleontologia } \\
\text { (primeira ocorrência), tetrápodes terrestres, } \\
\text { pelve, coluna vertebral, membros } \\
\text { inferiores, semelhanças anatômicas, } \\
\text { ancestral direto, arcos faríngeos, brânquias, } \\
\text { tubo neural, notocorda (primeira } \\
\text { ocorrência), eixo de sustentação, } \\
\text { desenvolvimento corporal, bases } \\
\text { nitrogenadas, rochas sedimentares } \\
\text { (primeira ocorrência), história evolutiva, } \\
\text { unidades químicas, material genético }\end{array}$ \\
\hline
\end{tabular}


No que tange à situacionalidade, vemos que o texto é apresentado em terceira pessoa: "Os membros anteriores de uma galinha, de um humano e de uma baleia não executam a mesma função". Em muitas ocasiões, o autor fez uso de vocativos para tentar aproximar o interlocutor: "Observe nas imagens a seguir os ossos da pelve e fêmur humanos".

Também evidenciamos algumas formas impessoais, tais como "nota-se que a estrutura óssea básica desses membros é a mesma", o que denota um distanciamento para com o frequentador. Também há presença de palavras e estruturas eruditas: "A notocorda representa o primeiro eixo de sustentação dos animais na fase embrionária". Também encontramos muitas terminologias: "Em todas as espécies o material genético é formado pelas mesmas unidades químicas, as bases nitrogenadas".

No que concerne à variedade dialetal, o texto apresenta-se em português brasileiro, variante do sudeste do país. Não evidenciamos regionalismos ou coloquialismos.

\section{Discussão}

De acordo com Krieger e Finatto (2004), Kuguel (1998) já preconizava que alguns termos somente poderiam ser explicados no interior do processo comunicacional, materializado pelo texto. Conforme nosso estudo, o tratamento das terminologias se realiza através de quatro categorias de tratamento: paráfrase explanatória, tratamento não reformulativo, compensação por elementos semióticos e inclusão de sinônimos entre parênteses. Também há de constar que a nossa análise constatou termos sem tratamento que se encaixaram na categoria nenhum.

Um grande número de termos foi tratado com o uso de paráfrases explanatórias, que se assemelham, em certa medida, àquelas constantes em dicionários e/ou livros didáticos de ciências do ensino fundamental.

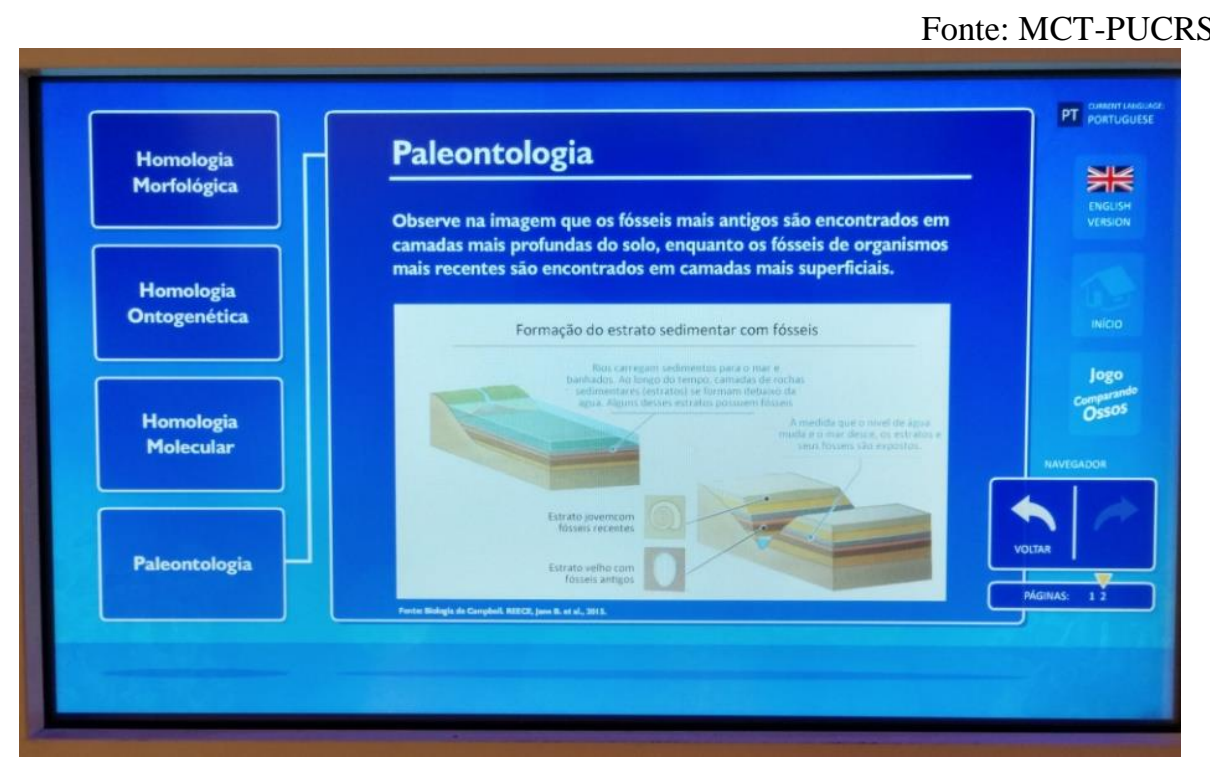

Figura 5 - Paleontologia 
O tratamento não reformulativo se materializou através de exemplificações dadas pelo produtor do texto acerca do conceito ao qual o termo se refere, sem necessariamente parafrasear esses conceitos. O termo "estruturas anatômicas" é seguido da informação apositiva "ossos e demais órgãos". Em "membros anteriores", implica-se que a "mão do humano" e a "nadadeira da baleia" são membros anteriores. Para "estruturas análogas", implica-se que as asas de uma ave e as asas de um inseto são exemplos de tais estruturas. Curiosamente, "estruturas análogas" também recebe tratamento através de uma paráfrase explanatória: "aquelas que compartilham semelhanças anatômicas, porém, apresentam funções distintas como, por exemplo, a nadadeira da baleia e a asa de um morcego". Trata-se de um tratamento não reformulativo, mas que ao mesmo tempo inclui uma paráfrase explanatória.

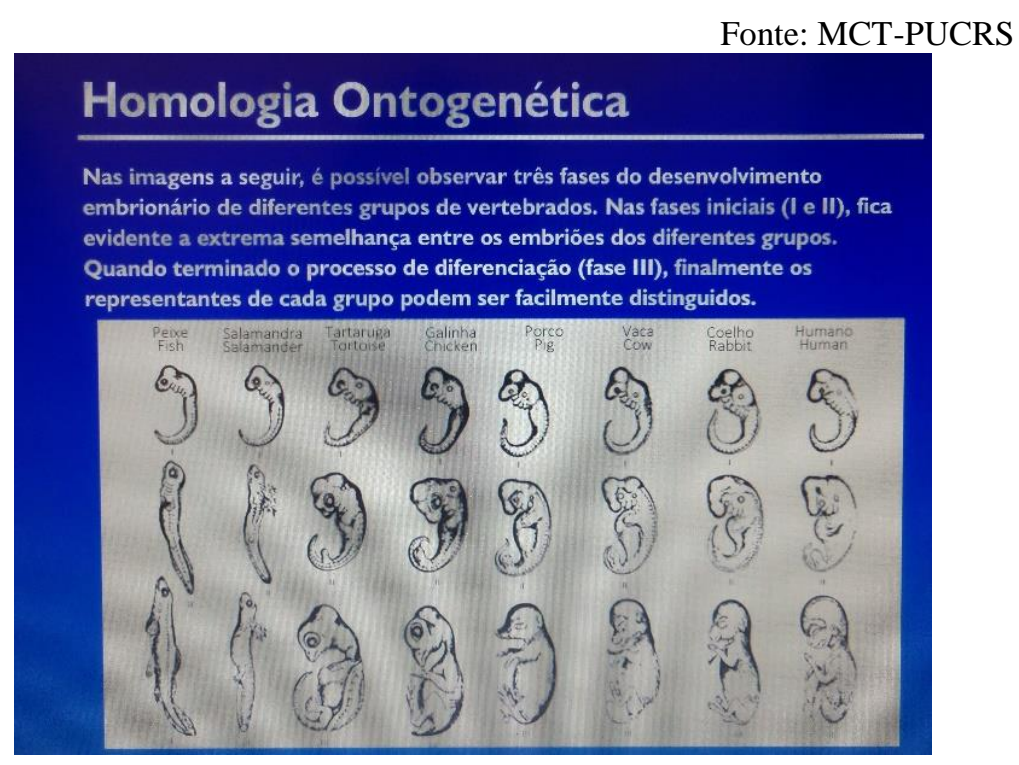

Figura 6 - Homologia Ontogenética

Quanto à compensação por elementos semióticos, alguns itens que talvez pudessem causar dificuldade de compreensão podem ser visualizados em imagens que aparecem nos totens, como "fêmur" (Figura 4), "estrutura óssea básica" (Figura 7) e "desenvolvimento embrionário" (Figura 6). Quanto a "processo de diferenciação" (Figura 6) e "espinhos abdominais" (Figura 4), embora fique implícito que as imagens fazem referência a esses termos, essa referência poderia ser melhorada através de setas, ou através da inclusão da indicação "fase III" no corpo da imagem (Figura 6).

Além destes procedimentos, uma modalidade de tratamento que é apresentada nos textos do MCT-PUCRS é a inclusão de sinônimos entre parênteses. Logo na tela inicial do totem (Figura 1), aparece o termo "Homologias" e um sinônimo entre parênteses: "similaridades". Na tela sobre Paleontologia (Figura 5), o termo "rochas sedimentares", em sua segunda ocorrência, é seguido do sinônimo "estratos".

Por fim, entre os elementos que não recebem nenhum tratamento, tem-se "ancestralidade comum", "ancestral comum", "pelve", "Paleontologia" (primeira ocorrência), "tetrápodes terrestres", "coluna vertebral", "membros inferiores", "semelhanças anatômicas", "ancestral direto", "arcos faríngeos", "brânquias", "tubo neural", "notocorda" (primeira ocorrência), "eixo de sustentação", "desenvolvimento 
corporal", "bases nitrogenadas", "rochas sedimentares" (primeira ocorrência), "história evolutiva" e "unidades químicas". No caso de "notocorda", o termo aparece em duas frases distintas em sequência, mas só na segunda frase é que há um real tratamento através de uma paráfrase explanatória. Vemos que a opção do produtor do texto por tratar os termos na segunda aparição não foi problemática. Com relação ao termo "registros fósseis", podemos dizer que a ele não é dado nenhum tratamento, mas a "fósseis" sim. Caberia, então, ao visitante associar o termo "registros fósseis" ao termo "fósseis" e tomá-los como sinônimos. No tocante a "material genético", que aparece em duas frases distintas em sequência, o produtor do texto optou por informar de que ele é feito em vez de defini-lo. Nesse caso específico, vemos a opção como problemática, pois as informações que seguem incluem termos que não são tratados e que podem dificultar o entendimento do visitante. Embora não recebam tratamento nesses textos, faz-se importante mencionar, ainda, que os termos "ancestralidade comum" e "ancestral comum" também aparecem em outros textos que compõem a grande exibição Marcas da Evolução. Entretanto, não há garantia alguma de que os visitantes tiveram contato com esses termos antes de ter tido contato com o trecho por nós analisado. Quanto aos elementos que aparecem mais de uma vez, mas recebem tratamento apenas na segunda aparição, fazemos um chamado para que lhes seja dado tratamento na primeira vez em que aparecem no texto.

Após a análise dos termos constantes neste artigo, vemos que no contexto de um museu de ciência e tecnologia, as terminologias devem receber algum tipo de tratamento com vistas a facilitar o entendimento do público visitante. Esse tratamento pode se materializar através de alguma das quatro modalidades de tratamento constantes neste trabalho ou, inclusive, através da reescrita dos textos, com o apoio de softwares que auxiliam a computar o nível de complexidade textual como, por exemplo, o CohMetrix-Port ou o Coh-Metrix-Dementia. Trabalhos anteriores, como o de Silva (2018), que se ocupou da reescrita de textos de divulgação científica, foram bastante exitosos nesse sentido.

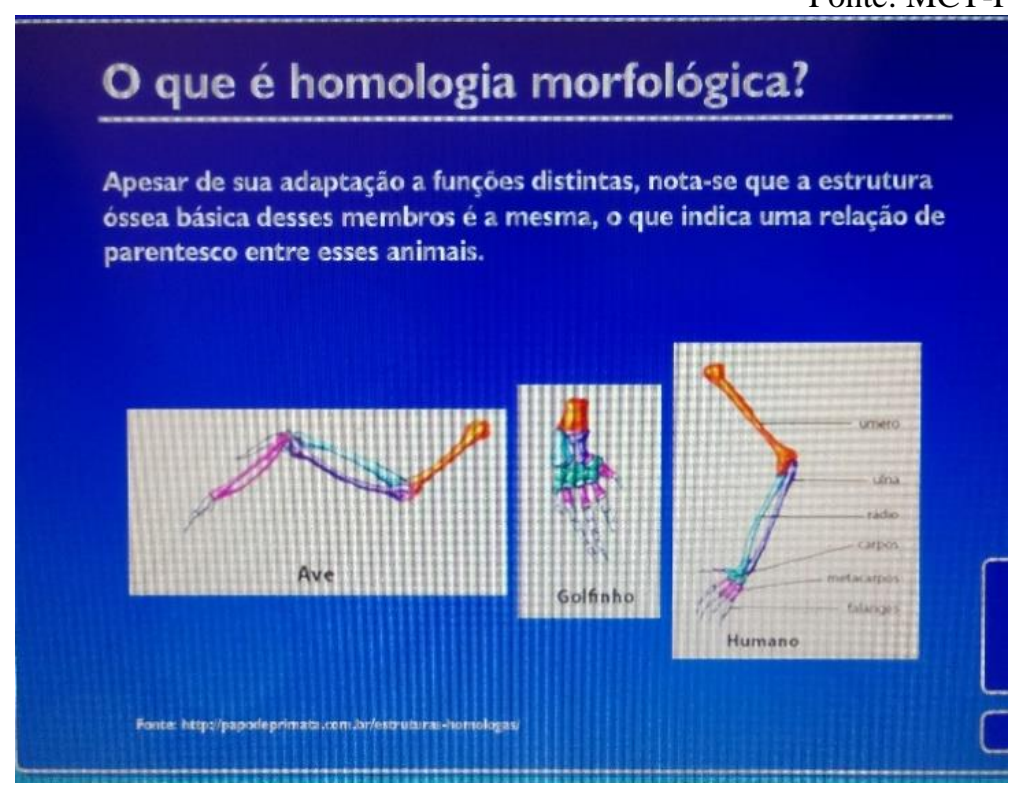

Figura 7: Estrutura óssea básica 
No que concerne à situacionalidade, o fato de o texto apresentar palavras eruditas, assim como terminologias não tratadas, dá-lhe um tom mais formal. Por esta razão, fazemos um chamado para um tratamento terminológico facilitador de modo que o mesmo se encaixe no nível de letramento de jovens em idade escolar, embora o MCTPUCRS, em particular, seja aberto para todas as audiências. Mesmo quando o texto é apresentado em uma variante linguística bastante próxima à variante usada na comunidade onde o museu está inserido, o uso de uma linguagem menos formal poderia ser benéfico para o visitante.

\section{Conclusão e perspectivas}

Pode-se dizer que os elementos elencados por Koch e Travaglia (1990) que têm influência na situacionalidade de um texto - grau de formalidade, variedade dialetal e tratamento a ser dado ao tema - podem ser ilustrados no contexto de um museu de ciências e tecnologia. Além disso, podemos dizer que o tratamento a ser dado ao tema abrange alguma forma de tratamento terminológico.

O senso de apropriação do conhecimento pode ser fortalecido através de diversos procedimentos, incluindo os quatro que são abordados neste artigo: paráfrase explanatória, tratamento não reformulativo, compensação por elementos semióticos e inclusão de sinônimos entre parênteses. Consequentemente, esses procedimentos tornam o texto relevante naquele contexto de comunicação museológica. Também constatamos que os textos do museu são, em certa medida, bastante dependentes da situação. Textos muito longos e com alta densidade de termos sem tratamento terminológico talvez não fossem bem recebidos por uma série de razões: a) a experiência se tornaria cansativa para o frequentador; b) o entendimento do texto, muitas vezes, é uma peça chave para a operação e manuseio de um experimento interativo. Caso o frequentador não se aproprie de como o experimento deve ser operado, ele estará simplesmente apertando botões ou puxando alavancas sem consciência do que aquilo quer representar e c) a dinâmica de funcionamento do museu seria prejudicada, já que se espera que os usuários circulem de experimento para experimento, desfrutando da experiência e despendendo uma quantidade de tempo razoável em cada um deles. Caso o usuário se depare com um texto longo e "difícill, o tempo que despenderá em um experimento será muito maior e impossibilitará outras pessoas de o utilizarem.

No caso específico de um museu de ciências e tecnologia, que é frequentado por audiências variadas, mas especialmente por jovens em idade escolar, observou-se, também, que a presença de elementos semióticos, como imagens, vídeos, apresentações em áudio, entre outros, pode despontar como um elemento facilitador, desde que empregadas de maneira qualificada. Em nossa análise, alguns termos são "explicados" através de imagens. Soma-se a isso o fato de se aumentar o dinamismo dentro do museu, já que o visitante pode fazer uma associação direta entre texto e realidade através da imagem. Constatamos que esse procedimento vai ao encontro dos preceitos do critério de situacionalidade.

Nos casos em que foram apresentadas paráfrases explanatórias, o produtor dos textos analisados privilegiou o termo e, em várias ocorrências, utilizou linguagem não 
rebuscada para explicá-lo ou para descrever sua funcionalidade. Acreditamos que isso se deve ao forte apelo didático de um museu de ciência e tecnologia em vista da divulgação científica.

Quanto aos termos que não receberam tratamento nenhum, vemos que, embora o tratamento possa aumentar o tamanho do texto, em alguns casos, essa omissão pode ser problemática e pode comprometer a situacionalidade, dependendo do protótipo de usuário que se tem em mente. Referimo-nos, em particular, aos casos em que não há nenhuma outra forma de associação entre o termo e o seu conceito. No caso específico do termo "material genético", que precede vários termos sem tratamento, aconselhamos que esse tipo de estrutura seja evitada. Por isso, acreditamos ser de extrema importância tratar as terminologias constantes nesse tipo de texto, visando o preenchimento dos critérios de textualidade.

Logo, podemos concluir que o tratamento terminológico - ou, nas palavras de Ciapuscio (1998), a reformulação denominativa dos termos - é uma estratégia que pode promover a situacionalidade de um texto em um museu de ciência e tecnologia. Como consequência, fazemos um chamado pelo reconhecimento das terminologias - e seu tratamento - como elemento componente da situacionalidade de um texto. Sabendo que a situacionalidade é o que faz um texto relevante em uma determinada situação, se os termos constantes nesse texto não estiverem acessíveis a seu público consumidor, pode se dizer que a situacionalidade está comprometida.

Como perspectivas para o estudo aqui relatado, vale situar que a produção textual, em suas diferentes tipologias, associada ao MCT-PUCRS é um campo fértil para estudos de Terminologia e Linguística. Por isso, sugerimos estudos posteriores com frequentadores do MCT-PUCRS para avaliar sua percepção sobre os textos na forma em que são apresentados dentro do museu. Em outras palavras, caberia uma análise da receptividade dos textos. Para tanto, seria importante estabelecer um protótipo de leitor específico, delimitando sua idade, nível de letramento, familiaridade com a leitura, entre outros fatores.

O fato de a exposição Marcas da Evolução ser uma exposição de grande magnitude para o MCT-PUCRS, com diferentes experimentos e textos, também seria um campo fértil para a Linguística Textual, especificamente no que concerne ao critério da intertextualidade, já que os textos e experimentos dialogam entre si, formando um todo de conhecimento. Nessa mesma linha, poderiam ser desenvolvidas pesquisas de cunho comparativo no âmbito dos Estudos do Texto, comparando os textos do MCTPUCRS com textos constantes em livros didáticos.

No que concerne à Terminologia mais especificamente, no caso de um texto com baixa receptividade, sugerimos a reescrita de alguns desses textos com foco em tratamentos terminológicos diferenciados e um estudo posterior envolvendo frequentadores de modo a avaliá-los. As conclusões dessa investigação poderiam ser de extrema valia para a comunidade de linguistas e museólogos, já que poderiam auxiliar esses profissionais na escolha das estruturas mais apropriadas na escrita de seus textos.

\section{REFERÊNCIAS}

BARROS, Diana Luz Pessoa de. Teoria Semiótica do Texto. 5a. ed. São Paulo: Editora Ática, 2011. 
BEAUGRANDE, Robert de; DRESSLER, Wolfgang. Introduction to Text Linguistics. London: Longman, 1981.

CIAPUSCIO, Guiomar Elena. La terminología desde el punto de vista textual:

selección, tratamiento y variación. Organon, Porto Alegre, v. 12, n. 26, p. 43-65, 1998.

FÁVERO, Leonor Lopes; KOCH, Ingedore Grunfeld Villaça. Linguística Textual: introdução. São Paulo: Cortez, 1988.

FIORIN, José Luiz. A noção de texto na semiótica. Organon, Porto Alegre, v. 9, n. 23, p. 165-175, 1995.

HALLIDAY, Michael; HASAN, Ruqaiya. Cohesion in English. London: Longman, 1976.

HOFFMANN, Lothar. Conceitos básicos da Linguística de Linguagens Especializadas. In: FINATTO, Maria José B.; ZILIO, Leonardo (org.). Textos e termos por Lothar Hoffmann, um convite para o estudo das linguagens técnico-científicas. Porto Alegre: Palotti, 2015a. p. 39-48.

Pesquisa de linguagens especializadas. In: FINATTO, Maria José B.; ZILIO, Leonardo (org.). Textos e termos por Lothar Hoffmann, um convite para o estudo das linguagens técnico-científicas. Porto Alegre: Palotti, 2015b. p. 55-66.

$\mathrm{KOCH}$, Ingedore Grunfeld Villaça. Introdução à linguística textual: trajetória e grandes temas. São Paulo: Contexto, 2004.

KOCH, Ingedore Grunfeld Villaça; TRAVAGLIA, Luiz Carlos. A coerência textual. São Paulo: Contexto, 1990.

KRIEGER, Maria da Graça; FINATTO, Maria José Bocorny. Introdução à Terminologia: teoria \& prática. São Paulo: Contexto, 2004. v. 1.

KUGUEL, Ines. Variación terminológica y correferencialidad textual. Organon, Porto Alegre v. 2, n. 26, p. 109-118, 1998.

LEIPNITZ, Luciane. Compostos nominais em língua alemã em medicina com tradução para o português. 2005. 132f. Dissertação (Mestrado em Letras) - Instituto de Letras, UFRGS, Porto Alegre, RS, 2005.

MARCUSCHI, Luiz Antônio. Produção textual, análise de gêneros e compreensão. São Paulo: Parábola Editorial, 2008.

MOTTA, Ester. Índices de complexidade textual em sentenças dos Juizados Especiais Cíveis do Poder Judiciário do Estado do Rio Grande do Sul. Inventário, Salvador, v. 1, n. 21, p. 35-50, 2018. 
PEARSON, J. Terms in context. Amsterdam; Philadelphia: Benjamins, 1998. (Studies in corpus linguistics, v. 1).

PEREIRA, Beatriz de Oliveira; VALLE, Mariana Guelero do. O discurso museológico e suas tipologias em um museu de história natural. Ciência e Educação (UNESP), Bauru, v. 23, n. 4, p. 835-849, 2017.

REECE, Jane et al. Biologia de Campbell. 10a. ed. Porto Alegre: Artmed, 2013.

SILVA, Asafe Davi Cortina da. Textos de divulgação para leigos sobre o transtorno do estresse pós-traumático em português: alternativas para a acessibilidade textual e terminológica. 2018. 427f. Dissertação (Mestrado em Letras) - Instituto de Letras, UFRGS, Porto Alegre, RS, 2018.

ZILIO, Leonardo. Verblexpor: um recurso léxico com anotação de papeis semánticos para o português. 2015. 197f. Tese (Doutorado em Letras) - Instituto de Letras, UFRGS, Porto Alegre, RS, 2015. 
APÊNDICE A - Texto originário da exposição Evidências da Evolução constante na nossa análise

\title{
Evidências da Evolução
}

As homologias (similaridades) morfológica, ontogenética e molecular são evidências que comprovam a ancestralidade comum e, portanto, a evolução das espécies. A paleontologia também assegura evidências nesse sentido. Confira:

\author{
Homologia Morfológica \\ Homologia Ontogenética \\ Homologia Molecular \\ Paleontologia
}

Homologia morfológica refere-se às similaridades entre estruturas anatômicas - como ossos e demais órgãos - e constitui-se em evidências da ancestralidade comum entre os seres vivos que as compartilham.

Os membros anteriores de uma galinha, de um humano e de uma baleia não executam a mesma função, ou seja, enquanto a asa da galinha é usada para voar, a mão do humano é usada para manusear e a nadadeira da baleia, para nadar.

Apesar de sua adaptação a funções distintas, nota-se que a estrutura óssea básica desses membros é a mesma, o que indica uma relação de parentesco entre esses animais.

\section{Órgão vestigiais}

Órgãos vestigiais são vestígios de estruturas presentes em um ancestral e que deixam de existir ou tornam-se atrofiadas em uma determinada linhagem de descendentes, devido à adaptação destes últimos a uma função diferente.

As baleias modernas são um exemplo disso. Nelas é possível observar vestígios da pelve e do fêmur, ossos que aparentemente não desempenham nenhuma função vital conhecida.

Entretanto, o fêmur e a pelve permanecem nos tetrápodes terrestres, com as funções de auxiliar no suporte da coluna vertebral e na união dos membros inferiores ao restante do esqueleto.

Por comprovar a ancestralidade comum entre as baleias e os tetrápodes terrestres, seus órgãos vestigiais são também evidências da evolução.

As serpentes da família Boidae (jiboias) também possuem vestígios da pelve e fêmur apresentando-se, atualmente, na forma de espinhos abdominais e não sendo utilizados para locomoção.

Observe nas imagens a seguir os ossos da pelve e fêmur humanos e os vestígios destes em baleias e serpentes atuais.

\section{Homologia X Analogia}

São ditas estruturas homólogas, aquelas que compartilham semelhanças anatômicas, porém, apresentam funções distintas como, por exemplo, a nadadeira da baleia e a asa de um morcego.

As estruturas homólogas originam-se do fenômeno evolutivo denominado radiação adaptativa: espécies com um mesmo ancestral que se diversificam de acordo com a adaptação ao meio. 
Por outro lado, as asas de uma ave e de um inseto, apesar de apresentarem a mesma função, não são semelhantes anatomicamente, indicando caminhos evolutivos distintos. São ditas estruturas análogas, aquelas que têm a mesma finalidade, porém, não apresentam-similaridade anatômica e, portanto, têm ancestralidade diferente.

Estruturas análogas originam-se do fenômeno evolutivo denominado convergência adaptativa: espécies que não têm um mesmo ancestral direto, mas apresentam uma característica semelhante devido à adaptação a um mesmo ambiente.

Homologia ontogenética refere-se às semelhanças anatômicas entre os indivíduos durante os primeiros estágios do desenvolvimento embrionário. Denomina-se embrião o estado jovem do animal, que se encontra no interior do ovo ou da fêmea.

Nos estágios do desenvolvimento embrionário de vertebrados observa-se uma cauda localizada em posição posterior ao ânus e estruturas chamadas arcos faríngeos que formarão as brânquias em peixes e parte das orelhas e garganta em humanos e outros mamíferos.

Nas imagens a seguir, é possível observar três fases do desenvolvimento embrionário de diferentes grupos de vertebrados. Nas fases iniciais (I e II), fica evidente a extrema semelhança entre os embriões dos diferentes grupos. Quando terminado o processo de diferenciação (fase III), finalmente os representantes de cada grupo podem ser facilmente distinguidos.

Nos estágios iniciais de desenvolvimento dos diferentes grupos de vertebrados, a cabeça aparece distinta do restante do corpo, assim como um tubo neural estendido ao longo da linha média, e uma notocorda: características herdadas de um ancestral comum.

A notocorda representa o primeiro eixo de sustentação dos animais na fase embrionária e, nos vertebrados adultos, será substituída pela coluna vertebral.

Apesar de algumas similaridades, ao longo do desenvolvimento, cada grupo de vertebrado apresenta diferenças no processo de desenvolvimento corporal.

Homologia molecular refere-se à semelhança no material genético dos seres vivos. Em todas as espécies o material genético é formado pelas mesmas unidades químicas, as bases nitrogenadas. Estas se organizam em genes, que são os responsáveis pelas informações hereditárias.

Uma variação na organização das bases nitrogenadas é que determina a variabilidade entre as espécies. Por outro lado, quanto mais semelhantes forem as sequências de genes, mais próxima é a história evolutiva dos grupos.

\section{Paleontologia}

Outra evidência da evolução das espécies é dada pela Paleontologia, ciência que estuda os registros fósseis. São considerados fósseis, restos ou traços de organismos como ossos e pegadas que ficaram preservados em rochas sedimentares ou no solo, e mostram que, durante eras passadas, a Terra havia sido habitada por espécies diferentes das que existem hoje.

A ordem na qual grupos de animais aparecem nas diferentes camadas de sedimentos permite traçar a história evolutiva desses organismos.

Observe na imagem que os fósseis mais antigos são encontrados em camadas mais profundas do solo, enquanto os fósseis de organismos mais recentes são encontrados em camadas mais superficiais. 


\section{Formação do estrato sedimentar com fósseis ${ }^{4}$}

Rios carregam sedimentos para o mar e banhados. Ao longo do tempo, camadas de rochas sedimentares (estratos) se formam debaixo da água. Alguns desses estratos

possuem fósseis. À medida que o nível da água muda e o mar desce, os estratos e seus fósseis são expostos.

Estrato jovem com fósseis recentes/Estrato velho com fósseis antigos. Ver Figura 5.

\footnotetext{
${ }^{4}$ Este último trecho, constante no bloco referente à Paleontologia, é proveniente de Reece et al (2013).
} 